Olena P. Mitryasova, Doctor of Pedagogical Sciences, Professor

ORCID https://orcid.org/0000-0002-9107-4448,e-mail: eco-terra@ukr.net

Anna S. Pryhodko, Master

e-mail: eco-terra@ukr.net

Petro Mohyla Black Sea National University, Mykolaiv, Ukraine

\title{
DETERMINATION OF THE DEPENDENCE BETWEEN CLIMATIC FACTORS AND COVID-19 DISEASE INCIDENCE
}

\begin{abstract}
The purpose of research consists in definition and an estimation of climatic factors influence on disease incidence of Covid-19 on an example of Mykolaiv city. In research we used such scientific methods: theoretical methods: analysis, synthesis, monitoring, systematization, generalization. For research facility, were held by calculations based on software Microsoft Excel. The calculations were performed using the formula correlation Results. The study examines the influence of climatic factors such as air temperature, humidity, solar radiation activity, wind speed, rainfall, and length of daylight. For the pair «Disease incidence - Temperature» the correlation coefficient is -0.74. For the pair «Disease incidence - Solar Radiation» correlation coefficient is -0.71. For the pair «Disease incidence - Daylight hours» correlation coefficient is -0.70. Humidity, as a derivative of air temperature, is evidenced by a comparison of decline periods and growth of these values. In the spring, along with the increase in temperature, the humidity dropped, and in the fall, when the air temperature dropped, the humidity increased. This factor also affected the spread of the virus in the second half of the year, when the humidity increased the virus began to spread faster. For the pair "Disease incidence - Humidity" correlation coefficient is +0.73 (average direct correlation). Other climatic factors, such as wind speed and rainfall, have not been shown to have a significant effect on the rate of disease spread. For the pair "Disease incidence - Wind speed» correlation coefficient is +0.32 , which corresponds to a weak direct correlation. For the pair «Disease incidence Rainfall» correlation coefficient is -0.30 , which indicates a weak inverse correlation. Conclusion. The results of the study show that the reduction of disease incidence is observed at high temperatures, high activity of solar radiation, and prolonged daylight, which determines the conditions for the prevention of such diseases and will improve the quality of life to achieve sustainable development.
\end{abstract}

Key words: climatic factors; correlation analysis; Covid-19 disease incidence; quality of life

\section{О.П. Мітрясова, А.С. Приходько}

Чорноморський національний університет імені Петра Могили, м. Миколаїв, Україна

\section{ВИЗНАЧЕННЯ ЗАЛЕЖНОСТІ МІЖ КЛІМАТИЧНИМИ ЧИННИКАМИ I ЗАХВОРЮВАНІСТЮ НА COVID-19}

\begin{abstract}
Анотація. Розглянуто залежності між кліматичними чинниками $i$ захворюваністю на Covid-19. Для визначення залежностей використано метод кореляційного аналізу. Проаналізовано тільки один з ймовірних складових впливу на захворюваність, а саме кліматичні чинники

(C) О.П. Мітрясова, А.С. Приходько, 2021
\end{abstract}

ISSN: 2411-4049. Екологічна безпека та природокористування, № 2 (38), 2021 
(температура повітря; вологість повітря; активність сонячної радіації; швидкість вітру; кількість опадів; довжина світлового дня). Визначено тісні зв'язки захворюваності з температурою повітря, активністю сонячної радіаиії, довжиною світлового дня, а також тісну зворотну залежність від вологості повітря (з коефіиієнтами кореляиії близько $\pm 0,9)$. Показано, щяо інші кліматичні характеристики, а саме: швидкість вітру $і$ кількість опадів, не мають сили впливу на швидкість розповсюдження захворювання. 3 'ясовані залежності можуть визначати умови проведення профілактики подібних захворювань, що надасть змогу покращити якість життя людини на шляху досягнення иілей сталого розвитку.

Ключові слова: кліматичні чинники; кореляційний аналіз; захворюваність на Covid-19; якість життя

DOI: 10.32347/2411-4049.2021.2.94-103

\section{Вступ}

Нині суспільство переживає важливий і критичний період своєї історії- період викликів для існування цивілізації через зростання низки негативних чинників: деградації природи, людської моралі, зростання бідності, поширення хвороб і голоду, агресії, набуття критичного рівня суперечностей між техносферою й біосферою. Разом з тим, сталий розвиток міст, спільнот та міцне здоров'я і благополуччя є одними з глобальних цілей для сталого розвитку суспільства $[1,2]$. 3 огляду на вищезазначене, значна увага приділяється вивченню причин, динаміки й особливостей розвитку екосистем різного рівня, визначенню та дослідженню взаємозв'язків між різноманітними екологічними чинниками, моделюванню різних природних i антропогенних процесів, складанню прогнозів й розробленню рекомендацій щодо подальшого сталого розвитку суспільства й біосфери загалом [3-6].

2020 рік став викликом для усього людства з огляду на пандемію Covid-19, яка $\epsilon$ знаковою в плані пошуків подальших напрямів розв'язання багатьох проблем соціуму, зокрема соціальних, економічних, екологічних, культурних тощо. Разом з тим, 2020 рік став також аномальним у плані температурного режиму атмосферного повітря - так, 18 лютого 2020 р. виявилося найтеплішим днем за останні 130 років метеорологічних спостережень. За останні 10 років середня температура повітря зросла на $1,0^{\circ} \mathrm{C} \pm 0,2^{\circ} \mathrm{C}$ вище доіндустріальних рівнів.

Так, певного наукового інтересу і значення набуває питання вивчення взаємозв'язку екологічної складової та якості життя людини, одним з аспектів якого є вивчення причин, динаміки й особливостей захворюваності населення у певних геохімічних провінціях, регіонах тощо.

Мета роботи полягає у визначенні та оцінюванні впливу кліматичних чинників на захворюваність на Covid-19 на прикладі міста Миколаєва.

Об'скт дослідження - захворюваність населення на Covid-19 та кліматичні чинники.

Предмет дослідження - взаємозв'язок між захворюваністю населення на Covid-19 і кліматичними чинниками.

\section{Методика дослідження}

Під час дослідження було використано такі методи: аналіз, синтез, систематизація, узагальнення. Розрахунки проведено на основі програмного 
продукту Microsoft Excel з використанням функції Corel. Значення кореляції можуть змінюватись між +1 та -1 , що, відповідно, показує пряму та непряму кореляційну залежність між обраними параметрами. Якщо значення знаходиться ближче до 1, то це означає наявність сильного зв'язку, а якщо ближче до 0, то слабкого. Якщо коефіцієнт кореляції негативний, це означає наявність протилежного зв'язку; чим вище значення однієї змінної, тим нижче значення іншої. Сила зв'язку характеризується також і абсолютною величиною коефіцієнта кореляції.

Так, на рис. 1 наведено приклад розрахунку функції кореляції за допомогою програмного забезпечення MS Excel.

\begin{tabular}{|c|c|c|c|}
\hline \multicolumn{2}{|c|}{ Тривалість світлового дня } & Приріст хворих & кореляция массив из 3x \\
\hline січень & 9 & 0 & 0 \\
\hline лютий & 10,25 & 0 & $=$ =КОРРЕЛ(СЗ:С5;Е3:ветер!H7Е5) \\
\hline березень & 11,75 & 4 & 0,913692513 \\
\hline квітень & 13,5 & 59 & 0,988731367 \\
\hline травень & 15 & 86 & 0,701704182 \\
\hline червень & 15,75 & 74 & -1 \\
\hline липень & 15,5 & 78 & $-0,989777866$ \\
\hline серпень & 14,25 & 341 & $-0,989539887$ \\
\hline вересень & 12,5 & 993 & $-0,984552787$ \\
\hline жовтень & 10,5 & 2435 & $-0,91613895$ \\
\hline листопад & 9,5 & 5733 & $-0,934327772$ \\
\hline грудень & 8,75 & 6040 & -1 \\
\hline
\end{tabular}

Рис. 1 - Приклад розрахунку кореляції між тривалістю світлового дня і захворюваністю на Covid-19

\section{Результати дослідження}

У процесі дослідження розглянуто вплив таких кліматичних чинників:

- температура повітря;

- вологість повітря;

- активність сонячної радіації;

- швидкість вітру;

- кількість опадів;

- довжина світлового дня.

Матеріали дослідження обирались з офіційних сайтів Міністерства охорони здоров'я України, Управління охорони здоров'я Миколаївської області, офіційного інформаційного порталу Міністерства охорони здоров'я України (Covid-19) і Українського гідрометеоцентру [7-11].

Разом 3 тим, аналізувалась динаміка захворюваності населення міста Миколаєва упродовж 2020 року. Узагальнені статистичні дані за 2020 рік щодо захворюваності на Covid-19 у світі, Свропі, Україні та в м. Миколаєві подано в табл. $1[7,8,11]$.

В Україні коронавірусну інфекцію Covid-19 (пневмонія нового типу) вперше було діагностовано 3 березня 2020 року в Чернівцях. 13 березня був зафіксований перший летальний випадок у результаті коронавірусної інфекції. Станом на 31 грудня 2020 року в Україні налічувалося 1055047 осіб, що захворіли, з них померли - 18533 осіб. 
Таблиця 1 - Кількість людей, які захворіли на COVID-19 (осіб) за 2020 рік

\begin{tabular}{|c|c|c|}
\hline Випадки захворювання & Випадки одужання & Летальні випадки \\
\hline \multicolumn{3}{|c|}{ у світі } \\
\hline 96,2 млн & $94,1 \mathrm{млн}$ & 2,06 млн $(2,14 \%)$ \\
\hline \multicolumn{3}{|c|}{ в Україні } \\
\hline 1055047 & 1036514 & $18533(1,8 \%)$ \\
\hline 21597 & у Миколаєві & $301(1,4 \%)$ \\
\hline
\end{tabular}

Вивчення залежностей між захворюваністю на Covid-19 і кліматичними чинниками здійснювалось на прикладі м. Миколаєва. Перший випадок захворювання на коронавірусну інфекцію Covid-19 (діагноз «пневмонія») в місті Миколаєві було зафіксовано 15 квітня 2020 року (на 9-ту годину ранку) у шестирічної дівчинки.

Відповідно до кліматичних характеристик регіону зазначимо, що місто розташовано на Півдні України, клімат якого помірно-континентальний 3 м'якою малосніжною зимою та жарким й посушливим літом (рис. 2). Територія Миколаєва розташована на південь від смуги високого тиску (вісь Воєйкова). Це зумовлює формування північно-східних континентальних повітряних мас зимового періоду й домінування й посилення західного (атлантичного) переносу повітряних мас влітку. Цю закономірність підтверджує Миколаївська метеорологічна станція, де за 52 роки спостережень мали перевагу (24\%) північно-східні вітри взимку, а влітку (21\%) - північнозахідні. Сумарна радіація на території Миколаєва складає 4400-4800 мДж/м², на півдні збільшується до 5000 мДж/м² за рік. Значення радіаційного балансу підстилаючої поверхні змінюється від 1880 до 2100 мДж/м².

Пересічна температура січня змінюється від $-5^{0} \mathrm{C}$ на півночі області і до $-2^{0} \mathrm{C}$ на півдні, де взимку близько 40\% днів є з відлигами, абсолютні мінімуми від $-30^{\circ} \mathrm{C}$ до $-34^{\circ} \mathrm{C}$. Пересічна температура липня досягає $20-23^{\circ} \mathrm{C}$, абсолютні максимуми $39-40^{\circ} \mathrm{C}$. Період 3 температурою понад $10^{\circ} \mathrm{C}$ становить $180-225$ днів. А тривалість вегетаційного періоду 215-225 днів. Розподіл річних сум опадів на території регіону зональний; на півночі області випадає 440-470 мм, у центральному і південно-східному районах 390-410 мм, а на південному заході 330-470 мм опадів. Кількість опадів зростає на 10-26\% на кожні 100 метрів 3 підвищенням висоти місцевості над рівнем моря. У вигляді злив iз загальної кількості опадів у теплий період (квітень - жовтень) випадає приблизно 70\% від усієї їх кількості.

За 27 років спостережень серед метеостанцій всього Причорномор'я найбільша кількість катастрофічних злив - вісім - було зареєстровано у Миколаєві (55 мм опадів). Сніговий покрив узимку в середньому від 37 до 65 днів. Пересічна потужність покриву снігу на півночі степової зони досягає 10 см, а на півдні не перевищує 3-6 см. Запаси води у снігу при найбільшій його висоті коливаються від 30 до 24 мм. Глибина промерзання грунту становить 37-54 см. Пересічна багаторічна вологість повітря складає 71\%, але іноді в травні - серпні вологість зменшується до 15-30\%. Щорічне надходження 3 опадами 150-170 кг/га хлоридів і сульфітів натрію та магнію пов'язане зі впливом моря. У степовій зоні області буває більше 15 днів із суховіями в теплий період (травень - серпень) [12]. 
У процесі дослідження проаналізовано залежність між парами вибірок даних (температура повітря - захворюваність; вологість повітря захворюваність та ін.) Кожний 3 кліматичних чинників порівнювався 3 приростом хворих на коронавірус у розглянутому діапазоні часу [13].

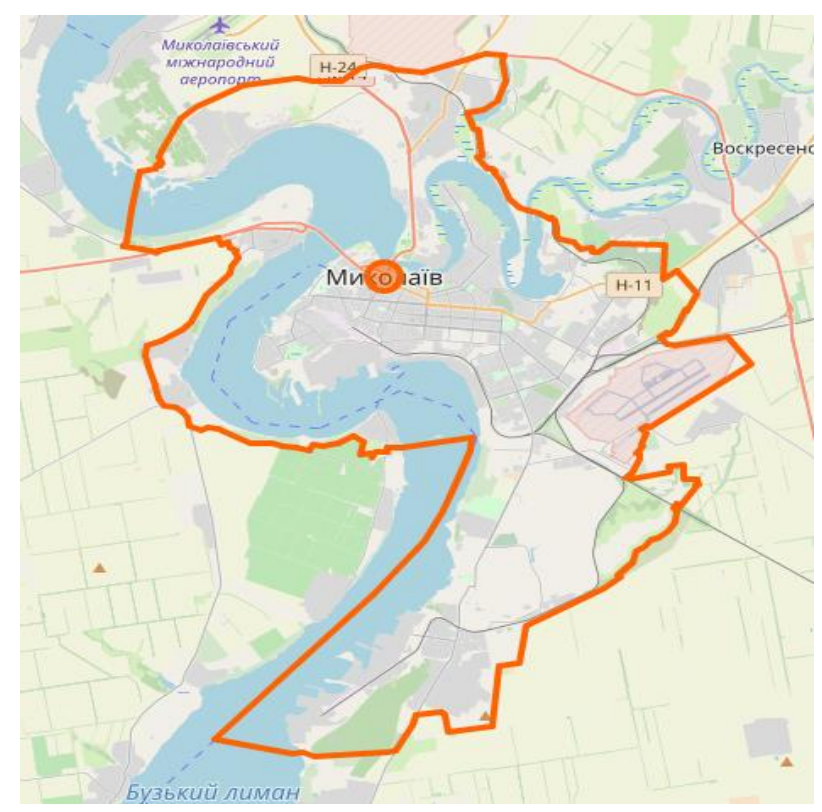

Рис. 2 - Карта міста Миколаєва [12]

За останні 100-120 років температура повітря в Миколаєві, так як і в цілому на Землі, має тенденцію до підвищення. Упродовж цього періоду середньорічна температура повітря підвищилася щонайменше на $10^{\circ} \mathrm{C}$. Найтеплішим за всю історію спостережень виявився 2007 рік. Значне підвищення температури відбувається у першу половину року. У середньому за рік у Миколаєві випадає 472 мм атмосферних опадів, найменше - у жовтні, найбільше - у липні. Мінімальна річна кількість опадів (230 мм) спостерігалася у 1896 році, максимальна (743 мм) зафіксована в 1955 році. Максимальну добову кількість опадів (144 мм) зафіксовано 30 червня 1955 року. У середньому за рік спостерігається 118 днів з опадами, найменше - у серпні (6), найбільше - у грудні (14). Щороку в Миколаєві утворюється сніговий покрив, проте його висота незначна. Відносна вологість повітря в середньому за рік становить 73\%, найменша - в серпні (60\%), найбільша - у грудні (86\%). Найменша хмарність спостерігається у серпні, а найбільша - у грудні.

Температура і вологість повітря характеризують загальний стан погоди, впливають на стан здоров’я людей, опір організму людини до захворювань.

На рис. 3 наведено графік зміни температури упродовж року на фоні приросту хворих на Covid-19. Загалом, така динаміка температури є цілком характерною для південного міста Миколаєва. 


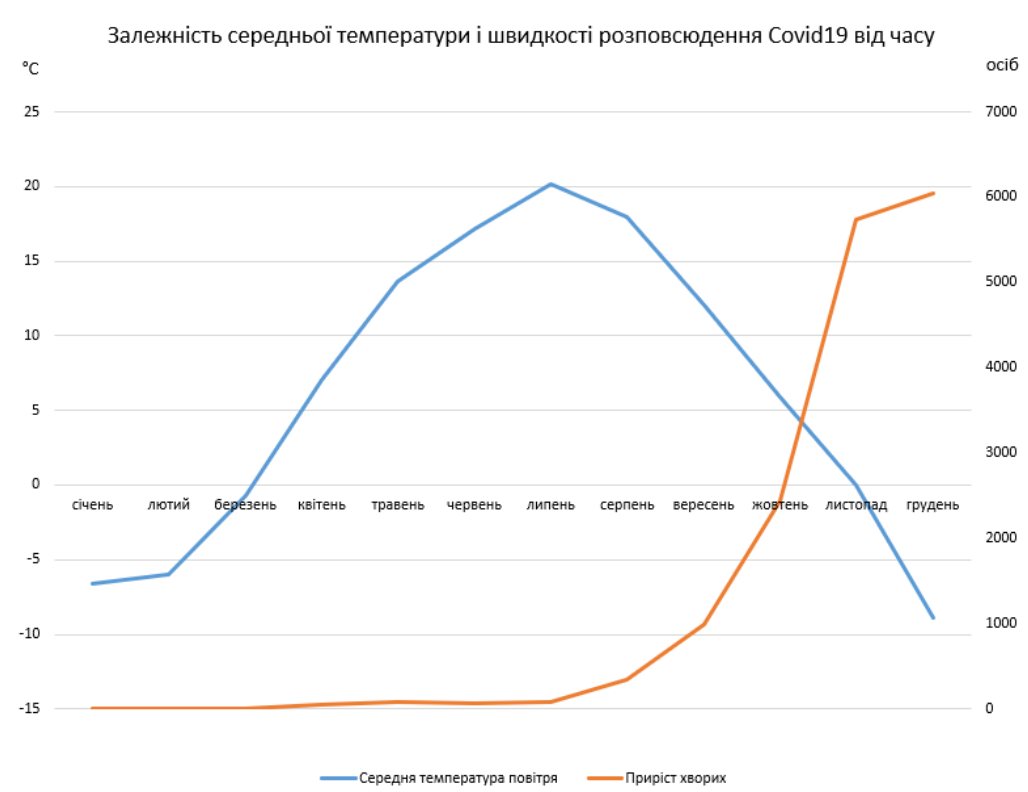

Рис. 3 - Динаміка зміни температури і захворюваності на Covid-19

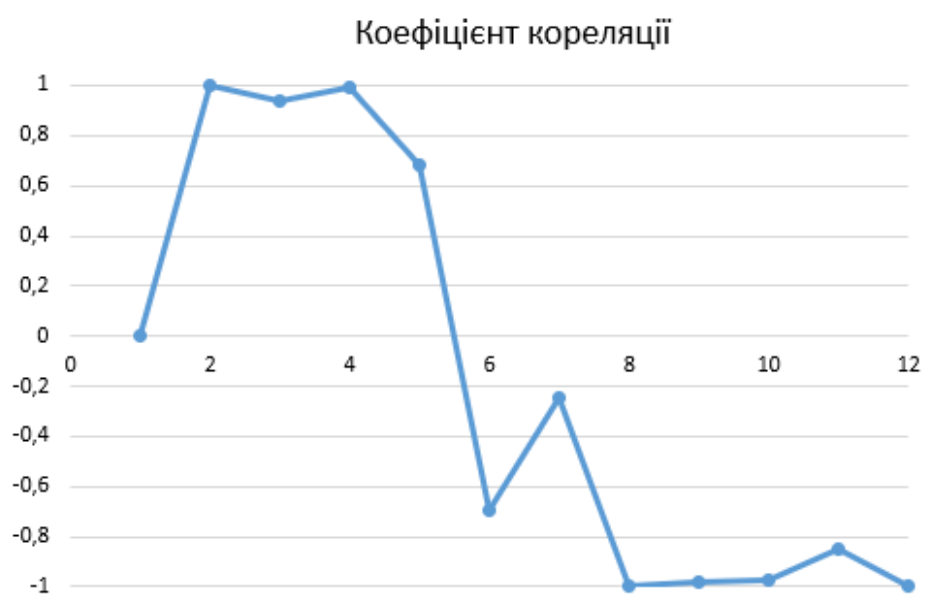

Рис. 4 - Кореляційна залежність температури повітря і захворюваності на Covid-19

Аналіз пари «вологість повітря - захворюваність на Covid-19» проведено аналогічно. Вологість повітря складає 0,85 одиниць на початку року в січні, зменшується до 0,65 влітку та знову починає зростати восени.

Графік зміни коефіцієнта кореляції подано на рис. 5. Відповідно до розрахунків, до середини року явного зв'язку не спостерігається, коефіцієнт коливається у межах від -1 до 0 (зимово-весняний період $(-0,5)-$ слабка кореляція). Після липня коефіцієнт має позитивне значення і наближається до +1 (осінньо-зимовий $+0,9$ ), що свідчить про сильну пряму кореляцію. Можна, відокремлено від інших чинників, стверджувати, що вологість повітря і рівень захворюваності сильно пов'язані в другій половині 2020 року. 


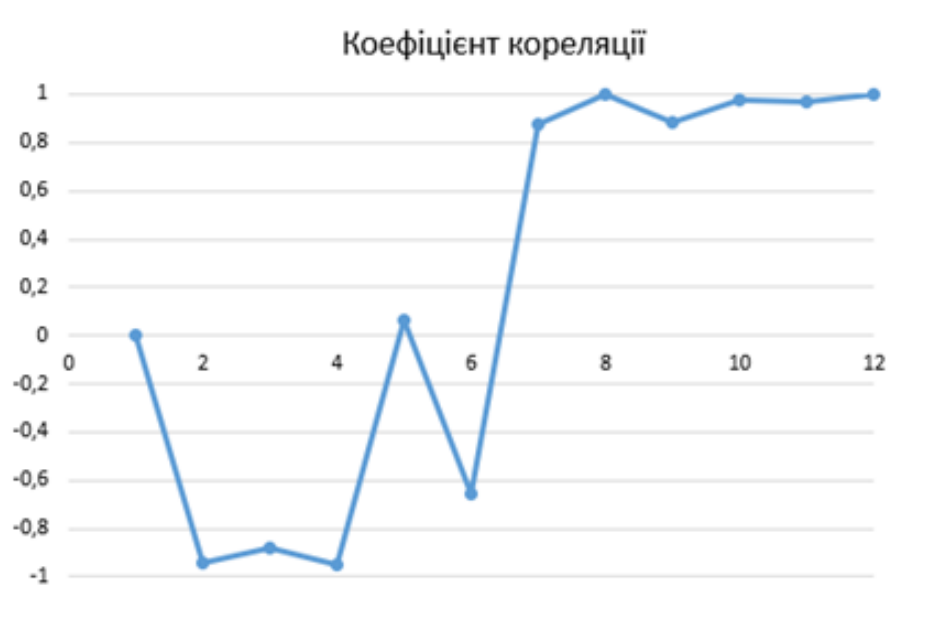

Рис. 5 - Зв'язок між вологістю повітря і захворюваністю на Covid-19

Проведено аналіз для пари «тривалість світлового дня - захворюваність». Визначено, що тривалість світлового дня, рівень сонячної радіації, середня температура і захворюваність є прямо пов' язаними величинами. Про це свідчить загальний графік на рис. 6, на якому показано зв'язок між тривалістю світлового дня і рівнем захворюваності на Covid-19. Коефіцієнт кореляції сягає -1 в другій половині року, що свідчить про сильний зворотний зв’ язок величин.

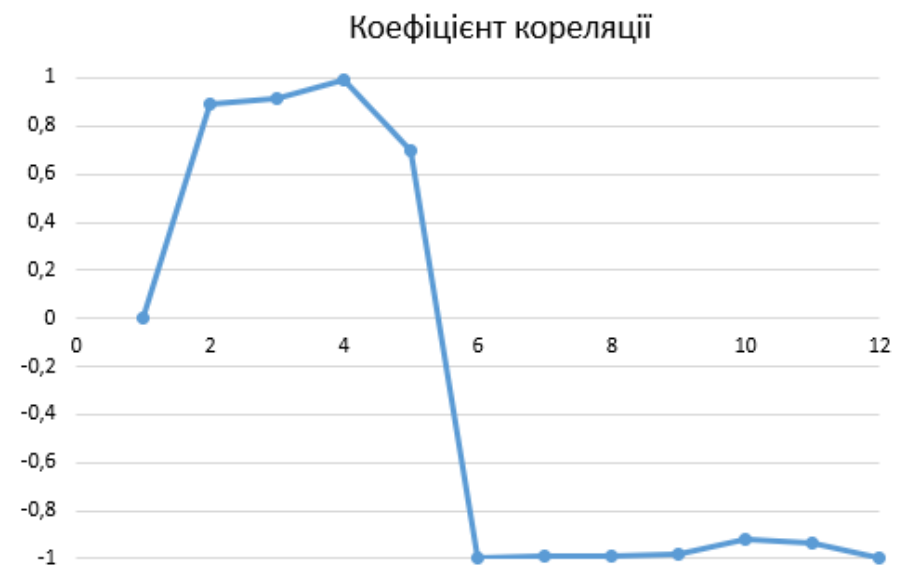

Рис. 6 - Кореляційна залежність тривалості світлового дня і захворюваності на Covid-19

Сонячна радіація є основним джерелом енергії на планеті Земля. Зважаючи на це, очевидним $є$ зв'язок сонячної радіації і температури повітря. На рис. 7 показано коефіцієнт кореляції між вказаними величинами. Пікове значення сонячної радіації в 6 кВт/м²/місяць зафіксовано влітку, що відповідає піковим значенням температури. Однозначно видно, що в другій половині року присутній сильний зворотний зв'язок. У зимово-весняний період наявна висока кореляція $(-0,8)$. У літній $(-0,9)$ - дуже сильна зворотна кореляція та у осінньозимовий - також сильна зворотна кореляція, показник складає близько $-0,9$. 
Кількість хворих значно зросла після вересня, що співпадає 3 сезонним падінням сонячної радіації. До кінця року кількість сонячної радіації продовжила знижуватися, а кількість хворих - рости. Однозначного причиннонаслідкового зв'язку встановити, опираючись на цю інформацію, неможливо, але відокремлено від інших чинників, можна стверджувати, що зростання захворюваності на Covid-19 пов'язано з рівнем сонячної радіації.

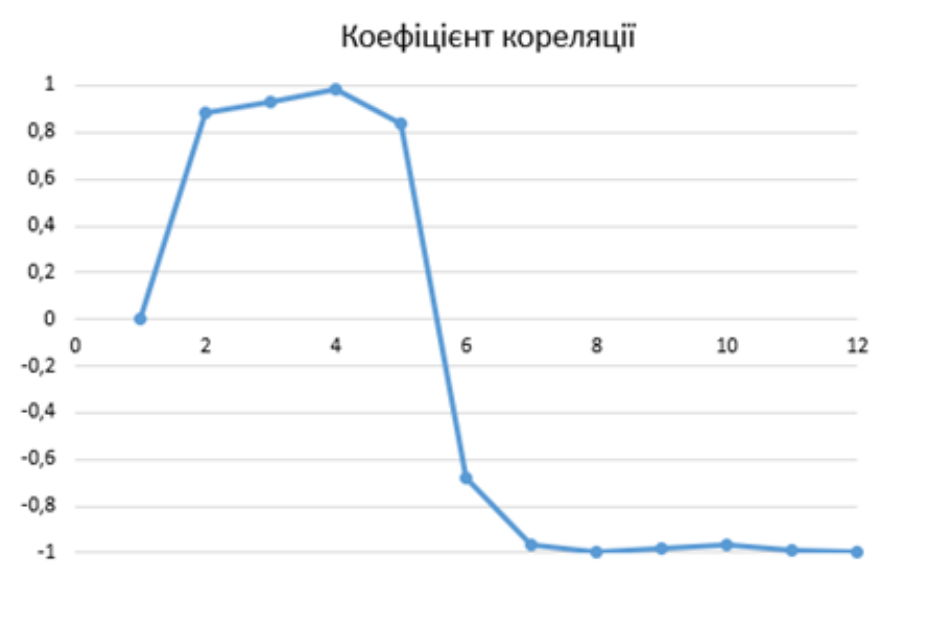

Рис. 7 - Кореляційна залежність сонячної радіації і захворюваності на Covid-19

Аналіз пари «швидкість вітру - захворюваність на Covid-19» проведено за аналогічною методикою. Середня швидкість вітру в Миколаєві за 2020 рік мала місце у межах норми з аномально вітряним квітнем. За квітень у місті пройшло декілька сильних вітрів, під час яких оголошували штормові попередження та які завдавали великих матеріальних збитків. Загальні показники наведено на рис. 8.

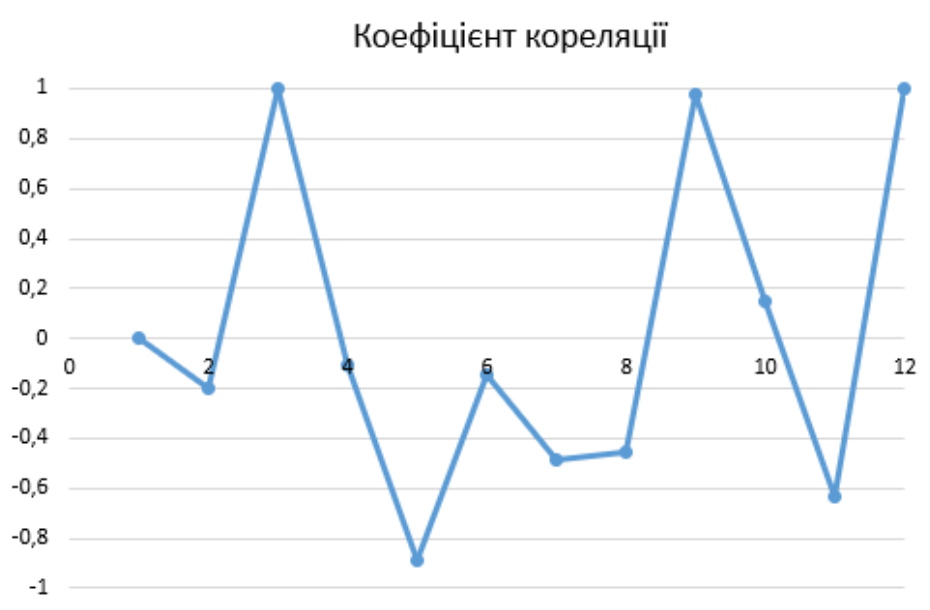

Рис. 8 - Зв’язок між швидкістю вітру і захворюваністю на Covid-19

За цим графіком видно, що очевидного зв'язку між швидкістю вітру і розповсюдженням вірусу не прослідковується. Коефіцієнт кореляції постійно 
коливається у межах від -1 до +1 . У зимово-весняний період простежується $(-0,4)$ слабка кореляція. У літній - слабка кореляція $(0,3)$ та у осінньо-зимовий теж слабка кореляція $(0,4)$. Виходячи 3 результатів аналізу, можна зробити висновок, що швидкість вітру ніяк не вплинула на розповсюдження Covid-19.

Визначено залежність між показниками кількості опадів і захворюваністю на Covid-19. Так, 2020 рік видався для Миколаєва доволі посушливим, близько 60 мм 3 піками в червні (120 мм) і вересні (100 мм). Так, зв'язку не спостерігається, що підтверджено кореляційним аналізом, результати якого наведено на рис. 9.

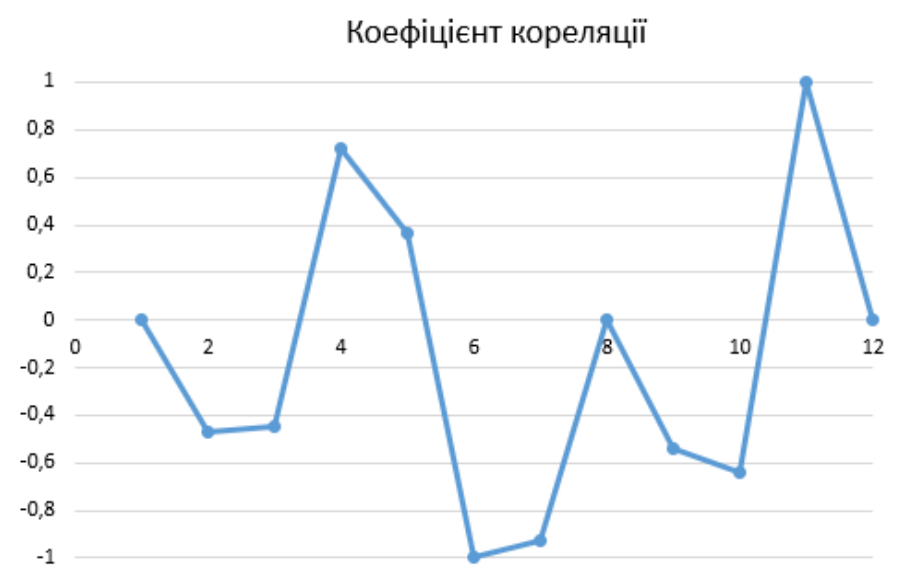

Рис. 9 - Кореляційна залежність кількості опадів і захворюваності на Covid-19

Коефіцієнт кореляції сильно коливався упродовж року. Набував значень в діапазоні від -1 до +1 з відсутніми періодами усталеного зв'язку. Означене свідчить про відсутність будь-якого зв'язку між розглянутими масивами даних. Отже, можна зробити висновок, що кількість опадів не вплинула на захворюваність на Covid-19. 3 точки зору механізму розповсюдження вірусу, збільшення кількості опадів має зменшувати поширення вірусу, але результати аналізу не дають повного підтвердження цієї гіпотези. Значна кількість опадів могла б допомогти в боротьбі $з$ пандемією, оскільки могла б змивати вірус 3 поверхонь. Деякі країни застосовували такий метод боротьби з ним.

\section{Висновки та перспективи подальших досліджень}

Залежність між кліматичними чинниками i захворюваністю на Covid-19 визначено. Проте, підкреслимо, що захворюваність населення - це багатофакторний процес, на який впливає багато чинників, зокрема природних, соціальних, економічних, біологічних тощо. Проаналізовано тільки одну 3 ймовірних складових впливу, а саме кліматичні чинники (температура повітря; вологість повітря; активність сонячної радіації; швидкість вітру; кількість опадів; довжина світлового дня). Визначено тісні зв'язки захворюваності 3 температурою повітря, активністю сонячної радіації, довжиною світлового дня, а також тісну зворотну залежність від вологості повітря (з коефіцієнтами кореляції близько $\pm 0,9)$. Показано, що інші кліматичні характеристики, а саме швидкість вітру і кількість опадів, не мають певної сили впливу на 
захворюваність на Covid-19. Визначені залежності можуть визначати умови проведення профілактики подібних захворювань, що надасть змогу покращити якість життя людини на шляху досягнення цілей сталого розвитку.

Результати даного дослідження не вичерпують повною мірою розв'язання означеного питання і потребують подальшого вивчення на прикладі інших регіонів та з урахуванням специфіки геохімічних провінцій територій.

\section{СПИСОК ЛІТЕРАТУРИ}

1. Natsionalna dopovid «Tsili staloho rozvytku: Ukraina» [National Report "Sustainable Development Goals: Ukraine"]. Retrieved from: http://un.org.ua/images/SDGs_National ReportUA_Web_1.pdf

2. Mitryasova, O., Pohrebennyk, V., Kochanek, A., \& Stepanova, O. (2017). Environmental Footprint Enterprise as Indicator of Balance it's Activity. In 17th International Multidisciplinary Scientific Geoconference SGEM 2017》 (ISSUE 51 - Ecology, Economics, Education and Legislation. - Vol. 17 - Ecology and Environmental Protection, pp. 371-378). Albena, Bulgaria.

3. Stepanenko, S.M., Polovyi, A.M., Loboda, N.S. et al. (2015). Climate change and their impact on the economy of Ukraine. Odesa: "TES" (in Ukrainian).

4. Pohrebennyk, V. Mitryasova, O., Klos-Witkowska, A., \& Dzhumelia, E. (2017). The Role of Monitoring the Territory of Industrial Mining and Chemical Complexes at the Stage of Liquidation In 17th International Multidisciplinary Scientific GeoConference SGEM 2017 (ISSUE 33 - Vol. 17 - Hydrology and Water Resources. pp. 383-390). Vienna, Austria.

5. Staddon, C. (2016). Managing Europe's Water Resoirces: Twenty-first Century Challenges. UK: University of the West of England.

6. Demianenko, M. (2018). Global development of mankind: strategies, threats, tendencies. Retrieved from: http://surl.li/nmvo (in Ukrainian).

7. Center for Disease Control and Prevention. Retrieved from: https://www.cdc.gov/

8. Information about the coronavirus. Retrieved from: https://moz.gov.ua/koronavirus2019-ncov

9. Ukrainian Hydrometeorological Center. Retrieved from: https://meteo.gov.ua/hmc.php

10. Coronavirus situation monitoring system. Retrieved from: https://covid19.rnbo.gov.ua/

11. National Security and Defense Council System for monitoring the situation with the coronavirus. Retrieved from: https://covid19.rnbo.gov.ua/

12. OpenStreetMap. Retrieved from: www.openstreetmap.org

13. Mitryasova, O.P., \& Prykhodko, A.S. (2021). Influence of climatic factors on the Covid-19 prevalence. In «Ecological safety - modern directions and prospects of higher education», coll. abstracts of the I International Internet Conference (pp. 90-92). Kharkiv: VN Karazin KhNU (in Ukrainian).

Стаття надійшла до редакиії 15.03 .2021 і прийнята до друку після рещензування 28.05.2021

\section{Мітрясова Олена Петрівна}

доктор педагогічних наук, професор кафедри екології Чорноморського національного університету імені Петра Могили

Адреса робоча: 54003, Україна, м. Миколаїв, вул. 68 Десантників, 10

ORCID https://orcid.org/0000-0002-9107-4448,e-mail: eco-terra@ukr.net

\section{Приходько Анна Сергіївна}

магістр Чорноморського національного університету імені Петра Могили

Адреса робоча: 54003, Україна, м. Миколаїв, вул. 68 Десантників, 10

e-mail: eco-terra@ukr.net 